\title{
Biochar and Nitrogen Fertilizers Effects on Growth and Flowering of Garland Chrysanthemum (Chrysanthemum Coronarium L.) Plant
}

\author{
Mariwan A. Ali \\ Ornamental Plant Dept, \\ Sulaimani Polytechnic University, \\ Sulaimani, Iraq \\ mariwan.ali@spu.edu.iq
}

\author{
Ardalan J. Mjeed \\ Ornamental Plant Dept. \\ Sulaimani Polytechnic University \\ Sulaimani, Iraq \\ ardalan.majeed@spu.edu.iq
}

\begin{abstract}
This experiment was conducted to study the effect two types of biochar and nitrogen fertilizers amendment, with different rates on morphological attributed of garland chrysanthemum plant. Two different types of biochar (BT) Eucalyptus biochar $(E B)$, and Salix biochar (SB), four biochar rates- BR (at $0,1,2$ and 3\%), and three rates of nitrogen fertilizer- NR (0, 140 and $\left.280 \mathrm{mg} \mathrm{kg}^{-1}\right)$ with three replications on plant growth were used in this research. The (Chrysanthemum coronarium L.) was used as a test plant to study some morphological characters including: Plant Height (PH) cm, Fresh Weight Per Plant (FWP) g, Number of Leaves Per Plant (NLP), Stem Diameter (SD) cm, Flower Diameter (FD), Number of Flower Per Plant (NFP) and Number of Flower Bud Per Plant (NFBP) cm. The Double Barrel Design was used for making biochar by pyrolysis system. The experiment was conducted in the plastic house condition. The results showed that biochar applications at a rate of 3\%, significantly increase $\mathrm{PH}$, $F W P, N L P, S D, F D$, and NFBP, while NFP increased only at 2\% biochar application and decrease at the 3\% rate. The application of $280 \mathrm{mg} \mathrm{kg}^{-1}$ of nitrogen significantly increased all of the parameters. The plant grown in the soils amended with the $\mathrm{EB}$ were higher than grown in the soils of the SB. In addition, the best value in the study was observed were biochar combined with nitrogen fertilizers.
\end{abstract}

Keywords: Biochar, Pyrolysis System, Garland Chrysanthemum, Nitrogen Fertilizer, Infertile Soil.

\section{INTRODUCTION}

Soilless media is used for the growth of most of the potted ornamental plants and peat is one of the soilless media component that traditionally used with a higher range [1]. Due to economic and environmental issue, recently farmers try to find an alternative to peat, vermiculite, perlite, and sand and among those products peat was largely applied in the production of ornamental potted plants [2,3]. Most of the media blends that are available in the markets have inaccurate properties such as acidity $(\mathrm{pH})$, the content of soluble salt, less nutrient amount and low cation exchange capacity (CEC) and these properties reduce the performance of the plant $[4$, 5]. Due to the above mentioned problems and in order to increase the production of ornamental plants an organic enhancement is required for biochar.
Biochar is basically charcoal used for agricultural purposes, which produced from thermo-chemical decomposition of organic matter changed to solid which is carbon-rich solid with little or without $\mathrm{O}_{2}$ conditions at temperatures between 300 and $1000^{\circ} \mathrm{C}$ by pyrolysis system, and contains some macro and micro-nutrients [6]. Carbon from biochar can be stabilized in the soil for extensive times, probably hundreds of years $[7,8]$.

Particle size distribution of biochar are differences based on the methodology and temperature of the production. When the temperature is high a quick pyrolysis occur and leads the production of fine-textured biochar with a short burn time while, slow pyrolysis with extended burn period cause the production of a coarse-textured biochar [9].

Therefore, biochar applications to soil have been shown to sequester $\mathrm{C}[7,10,11]$, increase plant growth in a variety of soils by improving soil chemical characteristics (e.g., nutrient retention, nutrient availability); physical characteristics (e.g, bulk density, porosity, cation exchange capacity CEC, and water holding capacity), and biological properties [12, 13].

Several studies reported that the total carbon [14], total nitrogen, available phosphorus, and exchangeable cations $(\mathrm{Ca}, \mathrm{Mg}, \mathrm{Na}$, and $\mathrm{K})$ increases with the addition of biochar to soil [15], and the soil $\mathrm{pH}$ value and some macro-and micronutrient increasing in the soil after the application of biochar with compost [16].

However, biochar has been reported to both rises [13] and decreases [17] plant growth and yield but there have been few studies recording the effect of biochar on ornamental growth.

The origin of annual herbaceous weed Chrysanthemum coronarium L. returns back to, Japan, China and Philippines [18, 19, 20, 21]. This plant have a big white and yellow crown, and the ability of the plant to adapt to local growing conditions make it easy to produce and spread and it is the most common flower growing in gardens and parks. 'Coronarium', is a variety of ornamental plant chrysanthemum which commonly known as garland chrysanthemum or crown daisy chrysanthemum. It is reported that the $\mathrm{C}$. coronarium ornamental plant and its other species are used as an edible food in Asian countries like China and Japan, in addition it has biological characteristic such as antioxidant activity, antibacterial, and antifungal characteristic [22]. 
The aim of this research was to illustrate the influence of two types of biochar and nitrogen fertilizers amendment, with different rates on morphological attributed of garland chrysanthemum plant.

\section{MATERIALS AND METHODS}

The present research was carried out during growing season 2015-2016 under plastic house condition in the Ornamental plant department, Technical Institute of Bakrajo, Sulaimani Polytechnic University, Sulaimani, Kurdistan region/Iraq. The effects of two types of biochar and nitrogen applications on chrysanthemum plant growth were tested by using four different biochar rate $(0,1,2$, and $3 \%$ biochar $(\mathrm{w} / \mathrm{w}))$, three different nitrogen rates $\left(0,140\right.$ and $280 \mathrm{mg} \mathrm{kg}^{-1} \mathrm{~N}$ - Urea) with three replications. Nitrogen fertilizers was added as Urea in two split application to each pots, which were 20 days after planting. The feedstock material used for the biochar production was (Eucalyptus Camaldulensis and Salix Babylonia) by pyrolysis system. While it was not statistically tested, there were differences for the measured chemical and physical properties among the different biochars.

The two types of biochar were alkaline, this is due to the formation of ash during the pyrolysis process, which typically consists of $\mathrm{Ca}, \mathrm{Mg}, \mathrm{K}$ and $\mathrm{Na}$ carbonates [23]. The amount of total carbon and $\mathrm{P}$ was very high in the EB than SB, and the EB contained high amounts of, K, $\mathrm{Mn}, \mathrm{Cu}$, and $\mathrm{Zn}$ compared with the SB (Table1).

Table 1: The concentration of macro-micronutrient and $\mathrm{pH}$ of (Eucalyptus (EB), and Salix (SB)) biochar.

\begin{tabular}{|c|c|c|c|c|c|c|c|c|c|c|}
\hline \multirow{2}{*}{$\begin{array}{c}\text { Biochar } \\
\text { Type }\end{array}$} & \multirow{2}{*}{$\frac{P}{\mathrm{mg} / \mathrm{kg}^{-1}}$} & \multirow{2}{*}{$\begin{array}{l}\mathrm{C} \\
\%\end{array}$} & $\mathbf{K}$ & $\mathrm{Ca}$ & Mg & $\mathrm{Na}$ & $\mathrm{Zn}$ & Mn & $\mathbf{C u}$ & \multirow{2}{*}{ pH } \\
\hline & & & \multicolumn{4}{|c|}{$\mathrm{mg} \mathrm{kg}^{-1}$} & \multicolumn{3}{|c|}{$\mathrm{mg} \mathrm{kg}^{-1}$} & \\
\hline EB & 138.34 & 56 & 1299.53 & 6345.09 & 567.23 & 179.76 & 8.34 & 18.23 & 0.78 & 9.12 \\
\hline SB & 111.23 & 42 & 1385.15 & 4217.89 & 344.78 & 90.48 & 5.66 & 17.62 & 0.41 & 9.21 \\
\hline
\end{tabular}

\subsection{Double Barrel Design for Making Biochar}

The double barrel design consists of a barrel in which biomass is placed, then as lightly larger barrel is placed over an inner barrel, and a cover (or lid) is placed on top, and it's a small scale. The lid has a chimney that helps control fair flow and gives heat more time to break down volatiles, resulting in a cleaner burn. The bottom section where the smaller barrel and the larger external barrel contact each other creates a seal to prevent oxygen entering but also acts as a pressure valve to allow gases to escape. Flammable gases and aerosols combust near the base of the inside barrel that further fuels the fire. This breaks down environmentally harmful gases such as methane $(\mathrm{CH})$ and carbon monoxide $(\mathrm{CO})$.

\subsection{Soil and Biochar Analysis}

The soil used in the study represent the dominant soil type of the region with low organic matter content, low alkaline $\mathrm{pH}$, low available $\mathrm{Zn}$ and $\mathrm{P}$ content, plant available $\mathrm{K}$ was also not at an adequate level and high available $\mathrm{Ca}$ and $\mathrm{Mg}$ content ( Table 2). Therefore, biochar applications had potentials to improve soil fertility by improving the availability of especially Nitrogen, Phosphorous, and Zinc, and the other micronutrients. The acidity $(\mathrm{pH})$ and $(\mathrm{EC})$ of soil and biochar were measured in $\mathrm{H}_{2} \mathrm{O}$ suspension by using a glass electrode - calomel electrode system [24]. The Walkley-Black method was used for determining Organic Matter (O.M) in soil samples [25]. The total organic carbon content of biochar was determined by dry ash method with $600^{\circ} \mathrm{C}$ with 3 hours muffle furnace ignition [25].UV-VIS spectrophotometer was used to determine the concentration of phosphorus in soil by using a solution of $0.5 \mathrm{~N}$ sodium bicarbonate $\mathrm{NaHCO}_{3}$ at $\mathrm{pH} 8.5$ [26].

Table 2: The properties of the soil that used in this research:

\begin{tabular}{lc}
\hline Parameters & value \\
\hline $\mathrm{pH}$ & 7.65 \\
$\mathrm{EC}(\mathrm{mmhos} / \mathrm{cm})$ & 2.0 \\
$\mathrm{CaCO} 3(\%)$ & 24.5 \\
$\mathrm{O} . \mathrm{M} .(\%)$ & 2.30 \\
$\mathrm{Ca}\left(\mathrm{mgkg}^{-1}\right)$ & 4521 \\
$\mathrm{Mg}\left(\mathrm{mgkg}^{-1}\right)$ & 223.2 \\
$\mathrm{Na}\left(\mathrm{mgkg}^{-1}\right)$ & 48.1 \\
$\mathrm{~K}\left(\mathrm{mgkg}^{-1}\right)$ & 203 \\
$\mathrm{P}\left(\mathrm{mgkg}^{-1}\right)$ & 4.07 \\
$\mathrm{Fe}\left(\mathrm{mgkg}^{-1}\right)$ & 9.22 \\
$\mathrm{Zn}\left(\mathrm{mgkg}^{-1}\right)$ & 1.43 \\
$\mathrm{Cu}\left(\mathrm{mgkg}^{-1}\right)$ & 2.60 \\
$\mathrm{Mn}\left(\mathrm{mgkg}^{-1}\right)$ & 27.2 \\
\hline
\end{tabular}

The DTPA-TEA extraction method that was developed by [27] for extracting metal micronutrients in neutral and calcareous soils were used for measuring plant available $(\mathrm{Mn}, \mathrm{Cu}, \mathrm{Fe}$, and $\mathrm{Zn}$ ) and for macronutrient another solution was prepared after extracting the soil samples by ammonium acetate $\left(1 \mathrm{~N} \mathrm{NH}_{4} \mathrm{OAc}\right)$ at $\mathrm{pH} 7.0$ [28] for assayed (Ca, $\mathrm{Mg}, \mathrm{K}$ and $\mathrm{Na}$ ) by using Perkin Elmer 3110 Atomic Absorption Spectrophotometer (AAS). The Total lime $\left(\mathrm{CaCO}_{3} \%\right)$ in soil was evaluated by using Scheibler Calcimeter method [29].

\subsection{Plant Characteristics}

All of the green part of the plants was harvested three months after planting to determine the morphological characteristic such as, Plant Height $(\mathrm{PH}) \mathrm{cm}$, Fresh Weight Per Plant (FWP) g, Number of Leaves Per Plant (NLP), Stem Diameter (SD) cm, Flower Diameter (FD), Number of Flower Per Plant (NFP) and Number of Flower Bud Per Plant (NFBP) cm. Finally, the plants were removed from the soil with attention then washed with normal water. 


\subsection{Statistical Analysis}

Experiment was performed by randomized complete block design (RCBD) with three replications was used in this study to test main and interaction effects. The data sets were analyzed with (IBM SPSS Advanced Statistics version 20.0.0). For direct comparison of treatments, Duncan's' Multiple Comparison tests were used. Analysis of variance (ANOVA) was used for testing the main effect, the interaction of all variables; Biochar type, Biochar rates and Nitrogen rates for all treatments at statistical significance level $(p \leq 0.05)$. The figures were designed using Graph pad prism version 6.0 software.

\section{RESULTS AND DISCUSSION}

The results of analysis of variance (ANOVA) for the different biochar types, biochar rates, nitrogen rates, and their interactions with some measured morphological characters of garland chrysanthemum plant are given in (Table 3). The main effects of all treatments were significant for the all morphological attributed measured for garland chrysanthemum plant except for NLP, and it was non-significantly affected by biochar types. The effects of the interaction of biochar type and the rate for the PH, FD, and the interaction effect of biochar type and nitrogen rate for the FD, and the interaction effect of biochar rates and nitrogen rate for the PH, NFBP, and the interaction effect among the biochar type and the rate, and the nitrogen rate for the PH, NLP, and NFP of the garland were not significant.

Increasing the nitrogen rate increased all the morphological attributes of the garland chrysanthemum plant (Table 4). Application of $\mathrm{N}$ together with the biochar positively affected plant growth $[13,30]$. The results further confirm that biochar as soil improvement can sufficiently use the nutrient amounts by carrying ammonium ions in the soils and preventing the nitrification of nitrogen [31]. The results of the previous study are in agreement with [32], observed morphological attributes such as the height of the plant, the leaves number, the flower number for each plant and the yield of the flower for each hectare when applied with the organic material at the rate of $10 \mathrm{t} \mathrm{ha}^{-1}$ and suggesting an amount of NPK in China aster. This result in the study agreed with [33], which reported that application of nitrogen $200 \mathrm{~kg}$ ha was significantly raised the height of the plant and the branches number of each plant in marigold.

Increasing the biochar rate also increased the all morphological attributes in the garland chrysanthemum plant (Table 5). The biochar applications increased NFBP significantly compared to the control ( $0 \%$ biochar). The NFP was highest at the $2 \%$ application but decreased at the highest biochar application rate (3\%).

Based on estimated marginal mean value, the effect of biochar types for morphological attributes of garland Chrysanthemum plant were compared together are given in (Table 6). In our experiments, all morphological attributed of the garland chrysanthemum plant grown in the soils amended with the EB were higher than grown in the soils of the SB. Similarly, the maximum diameter of the flower with the application of bio fertilizers along with recommended dose of NPK was reported by [34] in annual chrysanthemum. The amount of nutrients and $\mathrm{C}$ $\%$ of EB higher than SB due to high lignin content in biomass of EB (Table 1.) The biomass characteristic of the feedstock was essential due to its effect on the outcome pyrolysis products [35].

Table 3: The ANOVA results of the treatments and their interactions for the measured morphological attributes of garland chrysanthemum plant.

\begin{tabular}{|c|c|c|c|c|c|c|c|c|c|c|c|c|c|c|c|}
\hline \multirow{2}{*}{$\begin{array}{l}\text { Parameters } \\
\text { Source } \\
\end{array}$} & \multirow[b]{2}{*}{$D f$} & \multicolumn{2}{|c|}{$\begin{array}{c}\text { Plant } \\
\text { Height } \\
(\mathrm{cm})\end{array}$} & \multicolumn{2}{|c|}{$\begin{array}{c}\text { Fresh } \\
\text { Weight } \\
\text { Per Plant } \\
\text { (g) }\end{array}$} & \multicolumn{2}{|c|}{$\begin{array}{c}\text { No. of } \\
\text { Leaves } \\
\text { Per Plant }\end{array}$} & \multicolumn{2}{|c|}{$\begin{array}{c}\text { Stem } \\
\text { Diameter } \\
(\mathbf{c m})\end{array}$} & \multicolumn{2}{|c|}{$\begin{array}{l}\text { Flower } \\
\text { Diameter } \\
(\mathbf{c m})\end{array}$} & \multicolumn{2}{|c|}{$\begin{array}{c}\text { No. of } \\
\text { Flowers } \\
\text { Per Plant }\end{array}$} & \multicolumn{2}{|c|}{$\begin{array}{c}\text { No. of } \\
\text { Flower Buds } \\
\text { Per Plant }\end{array}$} \\
\hline & & F-Value & Sig. & F-Value & Sig. & F-Value & Sig. & F-Value & Sig. & F-Value & Sig. & F-Value & Sig. & F-Value & Sig. \\
\hline Biochar Type (BT) & 1 & 8.064 & 0.007 & 9.486 & 0.003 & 2.195 & 0.145 & 9.286 & 0.004 & 71.262 & 0.000 & 50.043 & 0.000 & 6.933 & 0.011 \\
\hline Biochar Rates (BR) & 3 & 119.896 & 0.000 & 48.817 & 0.000 & 34.143 & 0.000 & 65.455 & 0.000 & 62.336 & 0.000 & 21.903 & 0.000 & 9.657 & 0.000 \\
\hline Nitrogen Rates (NR) & 2 & 90.330 & 0.000 & 80.993 & 0.000 & 54.172 & 0.000 & 93.830 & 0.000 & 21.128 & 0.000 & 48.868 & 0.000 & 24.664 & 0.000 \\
\hline $\mathrm{BT} * \mathrm{BR}$ & 3 & 1.701 & 0.179 & 2.960 & 0.041 & 9.714 & 0.000 & 6.654 & 0.001 & 1.254 & 0.301 & 4.240 & 0.010 & 5.509 & 0.002 \\
\hline $\mathrm{BT} * \mathrm{NR}$ & 2 & 3.184 & 0.050 & 6.078 & 0.004 & 5.608 & 0.006 & 12.254 & 0.000 & 2.416 & 0.100 & 11.843 & 0.000 & 4.660 & 0.014 \\
\hline $\mathrm{BR}^{*} \mathrm{NR}$ & 6 & 1.875 & 0.090 & 13.862 & 0.000 & 3.695 & 0.004 & 11.387 & 0.000 & 3.519 & 0.006 & 3.271 & 0.009 & 1.939 & 0.093 \\
\hline $\mathrm{BT} * \mathrm{BR} * \mathrm{NR}$ & 6 & 1.223 & 0.149 & 10.792 & 0.000 & 1.329 & 0.263 & 6.110 & 0.000 & 2.232 & 0.056 & 1.771 & 0.125 & 2.392 & 0.042 \\
\hline
\end{tabular}

The raised amount of ash which is an inorganic element of the feedstock outcomes caused reduction the content of $\mathrm{C}$ in the out coming biochar [36]. The raised amount of holocellulose: the ratio of the lignin that contented in the biomass caused increasing the product of volatiles and caused reduction in the char product [35].In addition high lignin content in the feedstock biomass increases the yield of biochar [37]. In a few studies, biochar used for ornamental plant growth. Many overviews have presented verification to improve soil productivity by biochar [12].

Table 4: The effect of the nitrogen rates on some measured morphological attributes of garland chrysanthemum plant. 
Kurdistan Journal of Applied Research (KJAR) | Print-ISSN: 2411-7684 - Electronic-ISSN: 2411-7706 | kjar.spu.edu.iq Volume 2 | Issue 1 | June 2017 | DOI: 10.24017/science.2017.1.2

\begin{tabular}{cccccccc}
\hline $\begin{array}{c}\text { Nitrogen } \\
\text { Rate } \\
\left(\mathbf{m g} / \mathbf{k g}^{-\mathbf{1}}\right)\end{array}$ & $\begin{array}{c}\text { Plant } \\
\text { Height } \\
(\mathbf{c m})\end{array}$ & $\begin{array}{c}\text { Fresh weight } \\
\text { Per Plant } \\
(\mathbf{g})\end{array}$ & $\begin{array}{c}\text { No. of } \\
\text { Leaves } \\
\text { Per Plant }\end{array}$ & $\begin{array}{c}\text { Stem } \\
\text { Diameter } \\
(\mathbf{c m})\end{array}$ & $\begin{array}{c}\text { Flower } \\
\text { Diameter } \\
(\mathbf{c m})\end{array}$ & $\begin{array}{c}\text { No. of } \\
\text { Flowers } \\
\text { Per Plant }\end{array}$ & $\begin{array}{c}\text { Flower Buds } \\
\text { Per Plant }\end{array}$ \\
\hline 0 & $83.916 \mathrm{c}$ & $59.458 \mathrm{c}$ & $146.292 \mathrm{~b}$ & $1.330 \mathrm{c}$ & $4.736 \mathrm{c}$ & $4.464 \mathrm{c}$ & $14.132 \mathrm{c}$ \\
140 & $100.458 \mathrm{~b}$ & $78.042 \mathrm{~b}$ & $230.458 \mathrm{a}$ & $2.216 \mathrm{~b}$ & $5.363 \mathrm{~b}$ & $7.124 \mathrm{~b}$ & $18.492 \mathrm{~b}$ \\
280 & $108.00 \mathrm{a}$ & $84.333 \mathrm{a}$ & $226.750 \mathrm{a}$ & $2.666 \mathrm{a}$ & $5.670 \mathrm{a}$ & $9.000 \mathrm{a}$ & $24.681 \mathrm{a}$ \\
\hline
\end{tabular}

*Means in the same column followed by the same symbol are not significantly different at $\mathbf{p} \leq 0.05$ level based on Duncan test.

Table 5: The effect of the biochar rates on some measured morphological attributes of garland chrysanthemum plant.

\begin{tabular}{cccccccc}
\hline $\begin{array}{c}\text { Biochar } \\
\text { Rate } \\
(\%)\end{array}$ & $\begin{array}{c}\text { Plant } \\
\text { Height } \\
(\mathbf{c m})\end{array}$ & $\begin{array}{c}\text { Fresh Weight } \\
\text { Per Plant } \\
(\mathbf{g})\end{array}$ & $\begin{array}{c}\text { No. of } \\
\text { Leaves } \\
\text { Per Plant }\end{array}$ & $\begin{array}{c}\text { Stem } \\
\text { Diameter } \\
(\mathbf{c m})\end{array}$ & $\begin{array}{c}\text { Flower } \\
\text { Diameter } \\
(\mathbf{c m})\end{array}$ & $\begin{array}{c}\text { No. of } \\
\text { Flowers } \\
\text { Per Plant }\end{array}$ & $\begin{array}{c}\text { No. of } \\
\text { Flower Buds } \\
\text { Per Plant }\end{array}$ \\
\hline 0 & $75.278 \mathrm{~d}$ & $57.444 \mathrm{c}$ & $137.500 \mathrm{c}$ & $1.316 \mathrm{~d}$ & $3.893 \mathrm{c}$ & $4.720 \mathrm{c}$ & $13.560 \mathrm{~b}$ \\
1 & $95.277 \mathrm{c}$ & $74.277 \mathrm{~b}$ & $209.111 \mathrm{~b}$ & $1.811 \mathrm{c}$ & $5.425 \mathrm{~b}$ & $7.173 \mathrm{~b}$ & $20.280 \mathrm{a}$ \\
2 & $107.166 \mathrm{~b}$ & $82.390 \mathrm{a}$ & $224.944 \mathrm{ab}$ & $2.311 \mathrm{~b}$ & $5.682 \mathrm{ab}$ & $9.000 \mathrm{a}$ & $22.397 \mathrm{a}$ \\
3 & $112.111 \mathrm{a}$ & $81.667 \mathrm{a}$ & $233.111 \mathrm{a}$ & $2.844 \mathrm{a}$ & $6.020 \mathrm{a}$ & $6.563 \mathrm{~b}$ & $20.171 \mathrm{a}$ \\
\hline
\end{tabular}

*Means in the same column followed by the same symbol are not significantly different at $\mathbf{p} \leq \mathbf{0 . 0 5}$ level based on Duncan test.

Table 6: The effect of the biochar types on some measured morphologic attributes of garland chrysanthemum plant.

\begin{tabular}{lccccccc}
\hline Biochar Types & $\begin{array}{c}\text { Plant } \\
\text { Height } \\
(\mathbf{c m})\end{array}$ & $\begin{array}{c}\text { Fresh Weight } \\
\text { Per Plant } \\
(\mathbf{g})\end{array}$ & $\begin{array}{c}\text { No. of } \\
\text { Leaves } \\
\text { Per Plant }\end{array}$ & $\begin{array}{c}\text { Stem } \\
\text { Diameter } \\
(\mathbf{c m})\end{array}$ & $\begin{array}{c}\text { Flower } \\
\text { Diameter } \\
(\mathbf{c m})\end{array}$ & $\begin{array}{c}\text { No. of } \\
\text { Flowers } \\
\text { Per Plant }\end{array}$ & $\begin{array}{c}\text { No. of } \\
\text { Flower Buds } \\
\text { Per Plant }\end{array}$ \\
\hline Eucalyptus (EB) & $99.583 \mathrm{a}$ & $76.500 \mathrm{a}$ & $206.694 \mathrm{a}$ & $2.194 \mathrm{a}$ & $5.757 \mathrm{a}$ & $8.194 \mathrm{a}$ & $20.722 \mathrm{a}$ \\
Salix (SB) & $95.333 \mathrm{~b}$ & $71.389 \mathrm{~b}$ & $195.639 \mathrm{~b}$ & $1.947 \mathrm{~b}$ & $4.753 \mathrm{~b}$ & $5.528 \mathrm{~b}$ & $17.474 \mathrm{~b}$ \\
\hline
\end{tabular}

*Values represent based on estimated marginal mean.

Duncan's multiple comparison tests indicated that the all morphological attributed of the garland chrysanthemum plants grown in the soils amended with EB with the different application of nitrogen better than SB. In the unfertilized treatment, the $\mathrm{PH}$ had statistically increased by increasing the biochar rate and gets the high value at $3 \%(105.333) \mathrm{cm}$ followed at $2 \%(92.333) \mathrm{cm}$ and $1 \%$ (82.333)cm over $0 \%$ of biochar rate, although maximum increases $(122.667) \mathrm{cm}$ on $\mathrm{PH}$ was obtained in the fertilized treatment with $\mathrm{N}-280 \mathrm{mg} \mathrm{kg}^{-1}$ at $3 \%$ of biochar followed at $2 \%(118.333) \mathrm{cm}$ and \%1(109.667) over the $0 \%(84.000) \mathrm{cm}$ (Fig1 A). The FWP in the unfertilized treatments was increased at $2 \%$ (70.000) gm and decline (59.667) gm was observed at $3 \%$ rate then increases (63.000) gm at $1 \%$ and decreases (43.333) gm at $0 \%$ of biochar, while in the fertilized treatment with $\mathrm{N}-140 \mathrm{mg} \mathrm{kg}^{-1}$ the FWP statistically was increased at $3 \%$ (109.333) gm followed at 2\% (89.000) gm and at $1 \%$ (77.667) gm over the $0 \%$ of biochar (58.667) gm (Fig1 B). In the fertilized treatment $\mathrm{N}-140 \mathrm{mg} \mathrm{kg}^{-1}$ statistically the NLP increased by increasing the biochar rate $(351.000,292.000$, and 228.333) respectively over the control (142.667), in addition the NLP statistically increases by increasing the biochar rate in the unfertilized treatment $(192.000,166.000$, and 128.667) over the control (93.667) (Fig1 C). When the soil fertilized with $\mathrm{N}-280 \mathrm{mg} \mathrm{kg}{ }^{-1}$ the $\mathrm{SD}$ significantly increases at $3 \%$ rate $(5.100) \mathrm{cm}$ over the $0 \%$ rate $(1.533)$ $\mathrm{cm}$, and statistically there were no differences between 1 , and $2 \%$ rates $(2.900) \mathrm{cm}$, however in the unfertilized treatment the SD rising by increases of biochar rate, but statically there was similar effect between 1,2, and 3\% rate was sawed (1.633) cm over the control (1.066) $\mathrm{cm}$ (Fig1 D). The FD statistically there was no differences occur by increasing biochar rate $(6.770) \mathrm{cm}$ at $1 \%, 2 \%$, and $3 \%$ in the fertilized treatment with $\mathrm{N}-280 \mathrm{mg} \mathrm{kg}^{-1}$ but higher than control or $0 \%$ biochar $(5.233) \mathrm{cm}$, in the unfertilized treatment the FD statically increased by increasing biochar rate but there were no differences observed between $2 \%$, and $3 \%$ rate $(6.170) \mathrm{cm}$ followed at $1 \%(5.300) \mathrm{cm}$ over the $0 \%$ biochar $(3.370) \mathrm{cm}($ Fig1 E).the NFP increased by increasing biochar rate in unfertilized treatment but statically there was similar effect between $1 \%, 2$, and $3 \%$ rate was sawed (5.000) but higher than control (4.000), also in the fertilized treatment with $\mathrm{N}-280 \mathrm{mg} \mathrm{kg}^{-1}$ the NFP there was no liner relationship observed by utilized biochar rates, at $2 \%$ rate the NFP was (15.000) and decline (10.333) was observed at $3 \%$ then increases (12.333) at $1 \%$ and decreases (6.667) at $0 \%$ rate (Fig1 F). Finally the NFBP was higher (38.000) at $3 \%$ of biochar in fertilized treatment $\mathrm{N}-280 \mathrm{mg} \mathrm{kg}^{-1}$ and followed (30.000) at $1 \%$ rate then decreases $(26.000)$ at $2 \%$ rate over the control (20.667), also the maximum NFBP was showed (16.000) at $1 \%$ rate in unfertilized treatment over the control (4.333) (Fig1 G). 
A

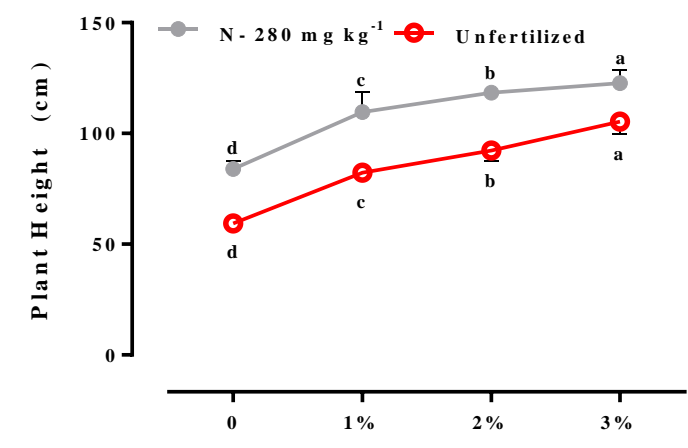

Eucalyptus Biochar $+\%$ Biochar

B

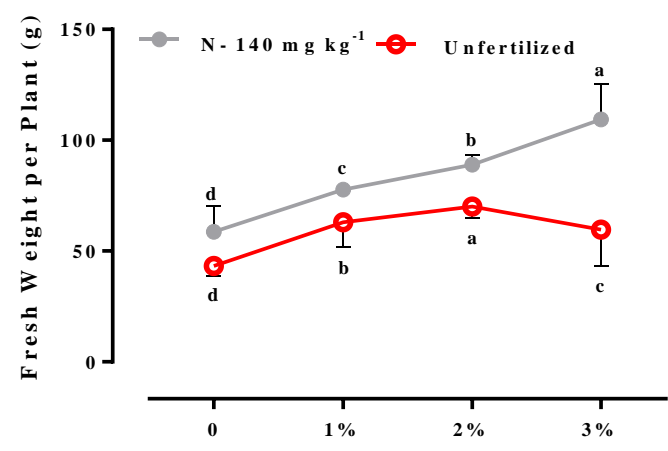

Eucalyptus Biochar + \% Biochar

C

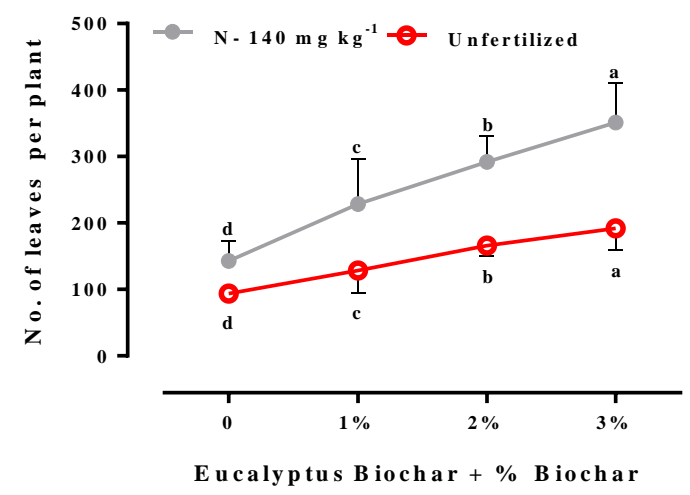

D

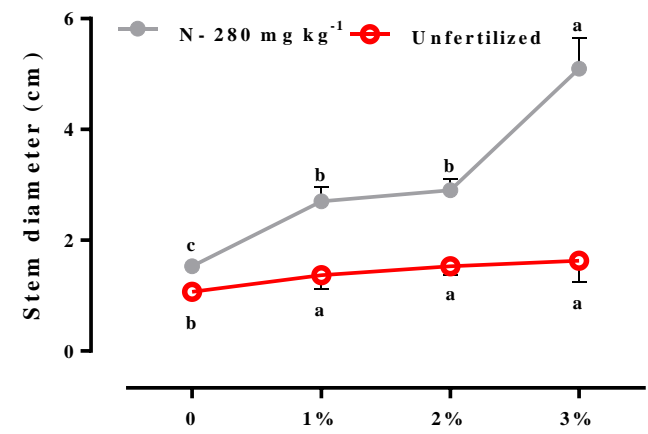

Eucalyptus Biochar + \% Biochar
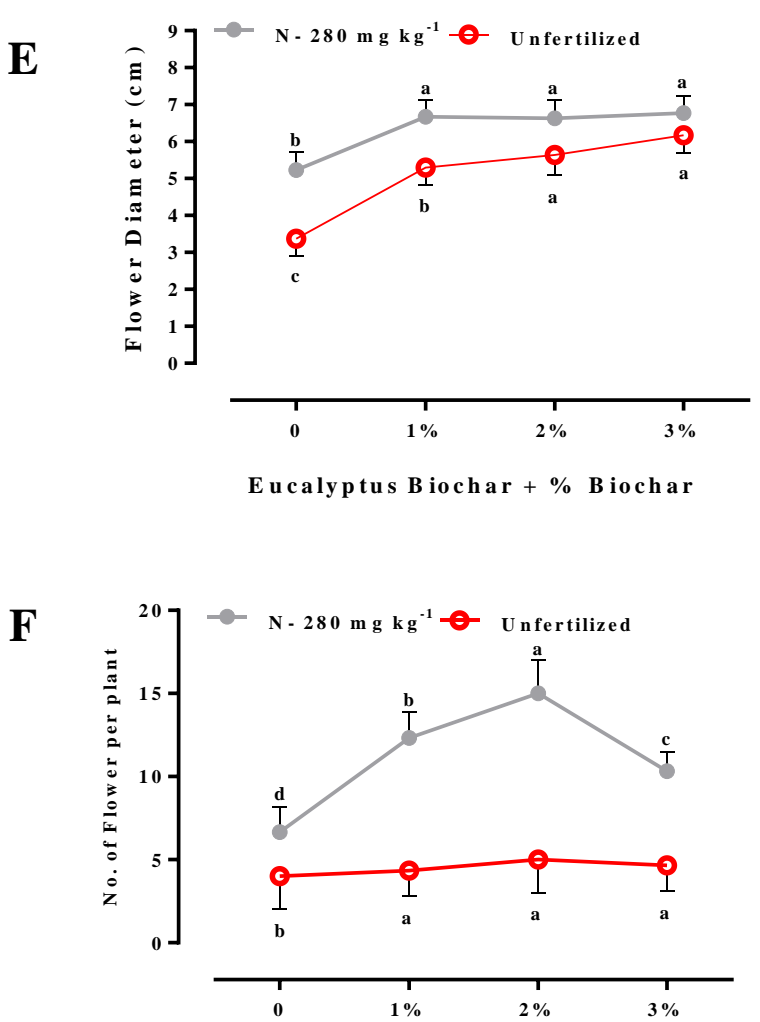

Eucalyptus Biochar + \% Biochar

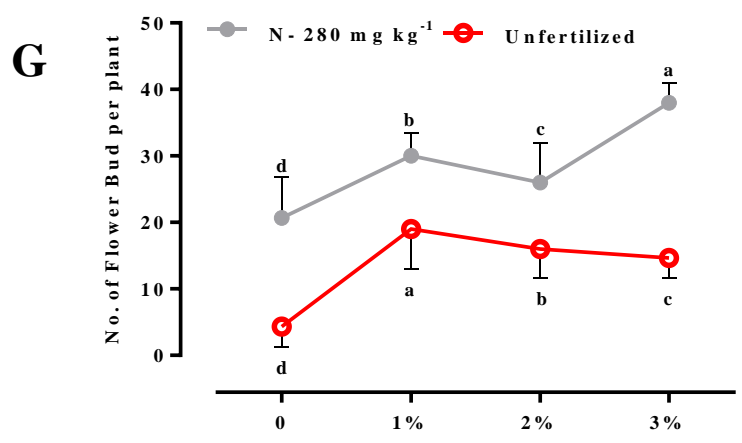

Eucalyptus Biochar + \% Biochar

Figure 1. Plant growth measurements (Mean $\pm \mathrm{SE}$ ) of garland chrysanthemum. Measurements contain Plant Height $(\mathrm{PH}) \mathrm{cm}$, Fresh Weight Per Plant (FWP) g, Number of Leaves Per Plant (NLP), Stem Diameter (SD) cm, Flower Diameter (FD), Number of Flower Per Plant (NFP) and Number of Flower Bud Per Plant (NFBP) cm. That figure illustrated the best interaction between biochar rates $(0,1,2$, and 3\%), two types of biochar (EB, and SB), and three Nitrogen rates $\left(0,140\right.$, and $\left.280 \mathrm{mg} \mathrm{kg}^{-1}\right)$, compare with non-fertilized treatment (Unfertilized). The abbreviation (a) means the greatest effect on plant morphological attributed. 


\section{CONCLUSION}

This study has highlighted the importance of balanced application different rate of nitrogen fertilizers with four rates of two types of biochar in garland chrysanthemum plant. During the experiment, we observed that Eucalyptus biochar had the greatest effect on vegetative plant growth, and generally $3 \%$ of biochar significantly was increased the morphological attributed of the plant over the control. Based on these results, it was observed that nitrogen rate $280 \mathrm{mg} \mathrm{kg}^{-1}$ had major effects and increases (PH, FWP, NLP, SD, FD, NFP, and NFBP). Finally, based on the FWP, significantly was the greatest interaction when soil amended with the combination of (Eucalyptus biochar, 3\% biochar rate, and $280 \mathrm{mg} \mathrm{kg}^{-1} \mathrm{~N}$ application).

\section{REFERENCES}

[1] M. Tullio, F. Calviello, and E. Rea, "Effect of compost based substrate and mycorrhizal inoculum in potted geranium plants," J. Life Sci. 6, 771-775, 2012.

[2] H. Cai, T. B. Chen, H. T. Liu, D. Gao, G. D. Zheng, and J. Zhang, "The effect of salinity and porosity of sewage sludge compost on the growth of vegetable seedlings," Sci. Hortic. 124, 381-386, 2010 .

[3] G. Y. Jayasinghe, "Sugarcane bagasses sewage sludge compost as a plant growth substrate and an option for waste management," Clean Technol. Environ. Policy 14, 625-632, 2011.

[4] E. Medina, C. Paredes, M. D. Pérez-Murcia, M. A. Bustamante, and R. Moral, "Spent mushroom substrates as component of growing media for germination and growth of horticultural plants," Bioresour. Technol. 100, 4227- 4232, 2009.

[5] L. Zhang, X. Y. Sun, Y. Tian, and X. Q. Gong, "Effects of brown sugar and calcium superphosphate on the secondary fermentation of green waste," Bioresour. Technol. 131, 68-75, 2013a.

[6] J. J. Manya, "Pyrolysis for Biochar Purposes," A review to establish current knowledge gaps and research needs, Environ. Sci. Technol. 46(15), 7939-7954, 2012.

[7] J. Lehmann, J. Gaunt, M. Rondon, 2006. "Biochar Sequestration in Terrestrial Ecosystems - A Review," Mitigation and Adaptation Strategies for Global Change, 11: 403- 427, 2006.

[8] M. W. I. Schmidt, M. S. Torn, S. Abiven, T. Dittmar, G. Guggenberger, I. A. Janssens, M. Kleber, I. Kogel-Knabner, J. Lehmann, D. A. C. Manning, P. Nannipieri, D. P. Rasse, S. Weiner, and S. E. Trumbore, "Persistence of soil organic matteras an ecosystem property," Nature. 478, 4956, 2011.

[9] M. Dall'Ora, P. A. Jensen, and A. D. Jensen, "Suspension Combustion of Wood: Influence of Pyrolysis Conditions on Char Yield, Morphology, and Reactivity," Energy \& Fuels, 22, 2955-2962, 2008.
[10] B. T. Nguyen, J. Lehmann, W. C. Hockaday, S. Joseph, and C. A. Masiello, "Temperature sensitivity of black carbon decomposition and oxidation," Environ. Sci. Technol. 44, 3324-3331, 2010.

[11] Y. Kuzyakov, I. Bogomolova, and B. Glaser, "Biochar stability in soil: decomposition during eight years and transformation as assessed by compound-specific C analysis," Soil Biol. Biochem. 70, 229-236, 2014.

[12] B. Glaser, J. Lehmann, W. Zech, “Ameliorating Physical and Chemical Properties of Highly Weathered Soils in the Tropics with Charcoal," A Review, Biology and Fertility of Soils, 35: 219230, 2002.

[13] M. Yamato, Y. Okimori, I. F. Wibowo, S. Anshori, M. Ogawa, "Effect of the application of charred bark of Acacia mangium on the yield of maize, cowpea and peanut, and soil chemical properties in South Sumatra, Indonesia," Soil Sic. Plant Nut. 52, 489-495, 2006.

[14] L. Van Zwieten, S. Kimber, S. Morris, K. Y. Chan, A. Downie, J. Rust, S. Joseph, and A. Cowie, "Effects of Biochar from Slow Pyrolysis of Paper Mill Waste on Agronomic Performance and Soil Fertility," Plant and Soil, 327, 235-246, 2010a.

[15] J. Major, M. Rondon, D. Molina, S. J. Riha, and J. Lehmann, "Maize Yield and Nutrition during 4 Years after Biochar Application to a Colombian Savanna Oxisol," Plant and Soil, 333 (1-2), 117 128, $2010 \mathrm{~b}$.

[16] J. Liu, H. Schulz, S. Brandl, H. Miehtke, B. Huwe, and B. Glaser, "Short-Term Effect of Biochar and Compost on Soil Fertility and Water Status of a Dystric Camisole in NE Germany under Field Conditions," J. Plant Nutration and Soil Sci. 175 (5): 698-707, 2012.

[17] J. L. Deenik, T. M. Clellan, G. Uehara, M. J. Antal, and S. Campbell, "Charcoal volatile matter content influences plant growth and soil nitrogen transformations," SSSA. Journal, 74, 1259-1270, 2010.

[18] T. G. Tutin, V. H. Heywood, N. A. Burges, D.M. Moore, D. H. Valentine, S.M. Walters, D.A. Webb, Flora Europaea. Plantaginaceae to Compositae, vol. 4. Cambridge University Press, Cambridge, pp. 459, 1976.

[19] B. Sebastián, A. M. Urzúa, and M. Vines, "Analysis of surface and volatile compounds of flower heads of introduced plants of Chrysanthemum coronarium L. growing wild in Chile," Flavour Frag. J. 21, 783 -785, 2006.

[20] A. Basta, C. M. Pavlovi, M. Couladis, and O. Tzakou, "Essential oil composition of the flowerheads of Chrysanthemum coronarium L. from Greece,” Flavour Frag. J. 22, 197-200, 2007.

[21] Sanchez-Monge, E.,"Flora agri'cola. Tomo I. Ministerio de Agricultura, Pesca y Alimentacio n Secretari'a General Te'cnica," Madrid, p.1294, 1991. 
[22] C. H. Zheng, T. H. Kim, K. H. Kim, "Characterization of potent aroma compounds in Chrysanthemum coronarium L. (Garland) using aroma extract dilution analysis," Flavour Frag. J. 19(5), 401-405, 2004.

[23] Yuan, J., R. Xu, W. Qian and R. Wang, "Comparison of the ameliorating effects on an acidic ultisol between four crop straws and their biochars," J. Soil. Sediment, 11, 741-750, 2011a.

[24] G. W. Thomas, "Soil pH and Acidity," In D.L. Sparks (eds.) Method of Soil Analysis: Chemical Methods. Part 3. SSSA. Madison, WI. P, 475-491, 1996.

[25] D. W. Nelson, L.E. Sommers, "Total Carbon, Organic Carbon, and Organic Matter," In D.L. Sparks (eds.) Methods of Soil Analysis, Part 3, Chemical Methods, SSSA. Book Series Number 5, SSSA., Madison, WI, P, 961-1011, 1996.

[26] S. Kuo, "Phosphorus," In D.L. Sparks (eds.) Methods of Soil Analysis, Part 3, Chemical Methods, SSSA Book Series Number 5, SSSA. Madison, WI, pp. 869 - 921, 1996.

[27] W. L. Lindsay, W. A. Norvell, "Development of a DTPA Micronutrient Soil Test for Zinc, Iron, Manganese, and Copper," SSSA. Journal, 42, 421428, 1978.

[28] P. A. Helmke, D. L. Sparks, "Lithium, Sodium, Potassium, Rubidium, and Calcium," In Sparks, D.L., (eds.) Methods of Soil Analysis, Part 3, Chemical Methods, SSSA. Series Number 5, Madison, WI, P, 551-574, 1996.

[29] R.H. Loeppert, D.L. Suarez, "Carbonate and Gypsum," In D.L. Sparks (eds.) Method of Soil Analysis: Chemical Methods. Part 3. SSSA. Madison, WI, p, 437-475, 1996.

[30] K. Y. Chan, L. Van Zwieten, I. Meszaros, A. Downie, and S. Joseph, "Agronomic Values of Greenwaste Biochar as a Soil Amendment," Australian Journal of Soil Research, 45 (8), 629634, 2007.

[31] K. Spokas, W. Koskinen, J. Baker, and D. Reicosky, "Impacts of Woodchip Biochar Additions on Greenhouse Gas Production and Sorption/Degradation of Two Herbicides in a Minnesota 25 soil," Chemosphere, 77, 574-581, 2009.

[32] Nethra, "Effect of organic and inorganic fertilizers on growth, yield and post-harvest life of china aster," M. Sc. (Agri), Thesis, Univ. Agric. Sci., Dharwad, 1999.

[33] S. Agarwal, N. Agarwal, A. Dixit, and R. N. Yadav, "Effect of $\mathrm{N}$ and KO on African marigold in Chattisgarh region," J. Orna. Hort., 5 (1), 86, 2002.

[34] N. Meshram, S. Badge, S. A. Bhongle, and S. D. Khiratkar, "Effect of Bio-Inoculants with Graded doses of NPK on Flowering, yield Attributes and Economics of Annual Chrysanthemum," Journal of Soils Crops, 18 (1), 217-220, 2008.
[35] E. M. Hodgson, D. J. Nowakowski, I. Shield, A. Riche, A. V. Bridgwater, J. C. Clifton- Brown, and I. S. Donnisona, "Variation in Miscanthus Chemical Composition and Implications for Conversion by Pyrolysis and Thermo-Chemical Bio-Refining for Fuels and Chemicals," Bioresource Technology, 102 (3), 3411- 3418, 2011.

[36] J. W. Gaskin, C. Steiner, K. Harris, K. C. Das, and B. Bibens, "Effect of Low - Temperature Pyrolysis Conditions on Biochar for Agricultural Use," Transactions of the ASABE, 51(6), 2061-2069, 2008.

[37] J. E. Amonette, S. Joseph, "Characteristics of Biochar: Microchemical Properties," In Biochar for Environmental Management: Science and Technology (eds.).Lehmann, J. and S. Joseph. London, Earth scan Publications, pp: 33-52, 2009.

\section{ACKNOWLEDGMENT}

The authors wish to express their deep thanks to to Prof. Dr. Hüseyin Dikici and Research Assist. Ömer Faruk Demir for all of their assistance with the analysis in soil laboratory, University of Kahramanmaras Sutcu Imam. I would like to thank my dear friends, especially Assist. Lec. Yaseen N Hassan Assist. Lec. Rebin A Qadir and for his kindness, help, and he supported me during my experiments.

\section{AUTHORS}

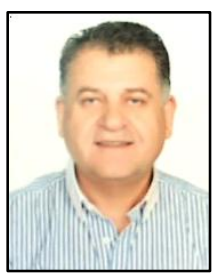

Mariwan A. Ali received his BSc in Agriculture/ Horticulture Department from Sulaimani university/ Iraq in 1978; MSc in Agriculture / Horticulture Department, specialization Ornamental plants and landscaping from Sulaimani university/Iraq in 2001. He is also head of Ornamental Plant Department in Bakrajo Technical Institute from Sulaimani Polytechnic University (SPU) /Iraq.

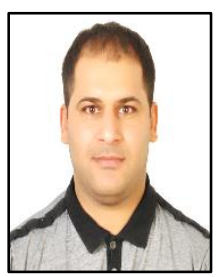

Ardalan J. Mjeed received the BSc degree in Agriculture / Soil and Water Department from Salahaddin University/ Erbil / Iraq in 2007; MSc in Bioengineering and sciences Department, Specialization Soil and Plant Nutrition from Kahramanmaras Sutcu Imam University / Turki in 2014. He is also Rapporteur of the Department of Ornamental Plants in Bakrajo Technical Institute from Sulaimani Polytechnic University (SPU) /Iraq. 